\title{
Influence Of Level Of Development Of Innovative Potential Of Region On Results Of Innovative Activity
}

\author{
Bakeeva Ioldyz \\ Department of Economics and Management at the enterprise \\ KNRTU-KAI \\ Kazan, Russia \\ jrbakeeva@gmail.com

\section{Bakeev Bulat} \\ Department of Economics and Management at the enterprise \\ KNRTU-KAI \\ Kazan, Russia \\ bakeev@gmail.com, ,
}

\author{
Trutnev Vyacheslav \\ Department of Economics and Management at the enterprise \\ KNRTU-KAI \\ Kazan, Russia \\ vvtrutnev@kai.ru \\ Mingaleev Gaziz \\ Department of Economics and Management at the enterprise \\ KNRTU-KAI \\ Kazan, Russia \\ mingaleevgaziz@mail.ru
}

\author{
Babushkin Vitaliy \\ Department of Economics and Management at the enterprise \\ KNRTU-KAI \\ Kazan, Russia \\ babushkinv@yandex.ru
}

\begin{abstract}
To date, the region's competitiveness and high economic growth are determined by its ability to offer innovation. Countries that have high levels of innovation become leaders in terms of economic development. Increasing the results of innovation is one of the most important areas of social and economic development of the region. High performance can be achieved by possessing a powerful innovative potential. The article examines some indicators of innovation potential and their impact on the results of innovation activity in the region. The level of costs for technological innovation and the number of personnel engaged in research and development have a significant impact on the results of innovation activities in the region. It was determined that a high index of innovation activity does not always lead to high results of innovation activity, which may be due to inefficient management when introducing innovations. The directions of improving the innovative potential of the region are the increase in the population of the region as a whole, the formation of scientific human resources, the formation of an effective system for managing the costs of innovation.
\end{abstract}

Keywords-Innovation, innovation, innovation potential, innovative activity, protection documents, scientific personnel

\section{INTRODUCTION}

At present, innovation is the most important driver of economic growth [6]. Countries with high rates of innovative activity are being selected as leaders by the level of economic development. For progressive innovative development, it is necessary to ensure the appropriate conditions [5]. The aggregate of resources that determine the possibility of implementing innovation activity is the innovation potential [8]. Essential components of the process of increasing the effectiveness of innovation in the region are the assessment and consideration of innovation potential [7]. A reliable economic evaluation of the innovation potential allows us to make sound management decisions on the innovative development of the region [1]. An urgent issue in this regard is the study of the influence of the level of innovative potential on the results of innovation.

\section{PRoblem StATEMENT}

The effectiveness of innovation, which determines the competitiveness of a country or region on the world market, depends on a large number of factors. It is necessary to determine what factors of innovation potential have the greatest impact on the results of innovation activity in the region. This will allow one to concentrate managerial influences on significant factors and not to spend efforts on insignificant things.

\section{RESEARCH QUESTIONS}

The following questions arising from the problem are analyzed: the distribution of innovative capacity elements in the Volga region, the effectiveness of innovation activity in the regional context, the dependence of the results of 
innovation activity on the availability of individual elements of the innovation potential

\section{PURPOSE OF THE STUdY}

The aim of the research is to identify the most significant elements of innovative potential that have the greatest impact on the effectiveness of innovation activities.

\section{RESEARCH METHODS}

Since 2007, the level of innovative development of countries has been assessed using the Global Innovation Index, calculated as a weighted sum of estimates of two groups of indicators. The first group includes resources and conditions for the implementation of innovations. It includes institutes (political conjuncture, legislative base, business environment), human capital and research, infrastructure, development of the domestic market (loans, investments, trade, competition), business development (employee knowledge, innovative links, knowledge acquisition). The first group of indicators, which determines the resources and conditions for the implementation of innovation activities, represents an innovative potential.

The second group represents the achieved results of innovation activity. It contains indicators of the development of technology and the knowledge economy (creation of knowledge, the impact of knowledge, the dissemination of knowledge) and the results of creative activity (intangible assets, creative goods and services, online creativity) [2].

\section{ANALYSIS}

Let us consider some indicators of innovative potential and the results of innovation activity of six republics of the Volga Federal District. The Republic of Tatarstan was leading in the volume of innovative goods, works and services in 2016, being three times ahead of the Republic of Bashkortostan following [3]. The Republic of Mari El had the lowest index in the same period. But in terms of growth in the volume of innovative goods, works and services, Mari El is ahead of all, having shown in five years (period from 2012 to 2016) an increase of 14 times. Also, a significant increase in this indicator of 4.4 times is observed in the Udmurt Republic. Only in the Chuvash Republic for this period there was a decline in the volume of innovative goods, works and services, accounting for $30 \%$ (see Fig. 1).

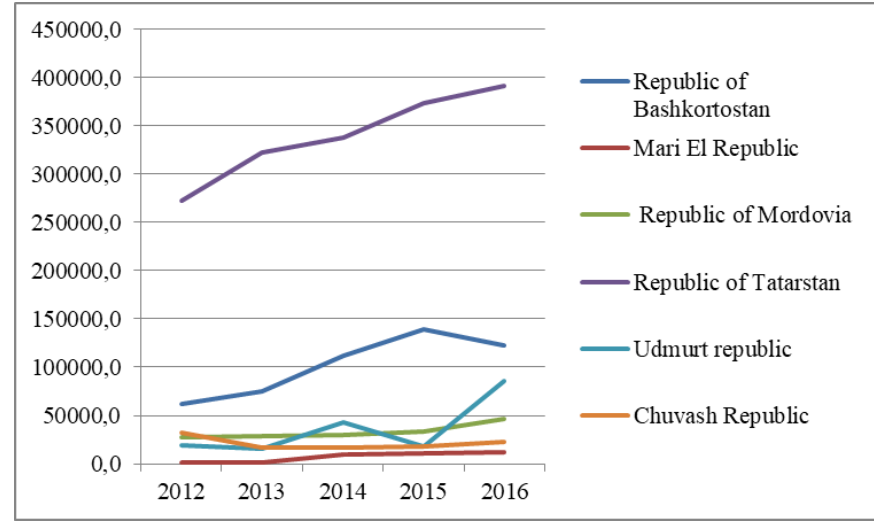

Fig. 1. The volume of innovative goods, works, services, million rubles.

The share of innovative goods, works and services in the total volume of shipped goods, works and services performed is the highest in the Republic of Mordovia, amounting to $27.2 \%$ in 2016. A positive trend is the growth of this indicator from 2012 to 2016 , equal to $19 \%$ (see table 1 ).

TABLE I. THE SHARE OF INNOVATIVE GOODS, WORKS, SERVICES IN THE TOTAL VOLUME OF GOODS SHIPPED, WORKS PERFORMED, SERVICES, IN PERCENT.

\begin{tabular}{|l|c|c|c|c|c|}
\hline & $\mathbf{2 0 1 2}$ & $\mathbf{2 0 1 3}$ & $\mathbf{2 0 1 4}$ & $\mathbf{2 0 1 5}$ & $\mathbf{2 0 1 6}$ \\
\hline $\begin{array}{l}\text { Republic of } \\
\text { Bashkortostan }\end{array}$ & 6.0 & 6.2 & 8.2 & 10.7 & 8.4 \\
\hline $\begin{array}{l}\text { Mari El } \\
\text { Republic }\end{array}$ & 1.0 & 2.2 & 10.4 & 9.2 & 8.2 \\
\hline $\begin{array}{l}\text { Republic of } \\
\text { Mordovia }\end{array}$ & 22.9 & 23.9 & 26.9 & 27 & 27.2 \\
\hline $\begin{array}{l}\text { Republic of } \\
\text { Tatarstan }\end{array}$ & 18.4 & 21.1 & 20.5 & 20.4 & 19.6 \\
\hline $\begin{array}{l}\text { Udmurt } \\
\text { republic }\end{array}$ & 6.4 & 4.8 & 11.2 & 4 & 16.3 \\
\hline $\begin{array}{l}\text { Chuvash } \\
\text { Republic }\end{array}$ & 22.6 & 12 & 12.1 & 12.2 & 13.1 \\
\hline
\end{tabular}

Almost all republics of the Volga Federal District have seen an increase in the share of innovative goods, works, services in the total volume of shipped goods, works and services. A huge breakthrough in this indicator was made by the Republic of Mari El, having shown an increase of eight times from 2012 to 2016. A significant 2.5-fold increase over the period under study is also observed in the Udmurt Republic. Only in the Chuvash Republic, the share of innovative goods, works, services in the total volume of shipped goods, works performed, services fell almost twice from 2012 to 2016.

Despite the low production of innovative products, in the Chuvash Republic the greatest innovation activity of organizations is noted. During the analyzed period in this republic the number of organizations that implemented innovations grew by $17 \%$. Also here is the highest percentage of organizations implementing innovations, which in 2016 was $24.5 \%$. In the Republic of Tatarstan, the innovative activity of organizations increased by $11.5 \%$ from 2012 to 
2016, the share of organizations that implemented innovations in 2016 was $21.3 \%$ (see Fig. 2).

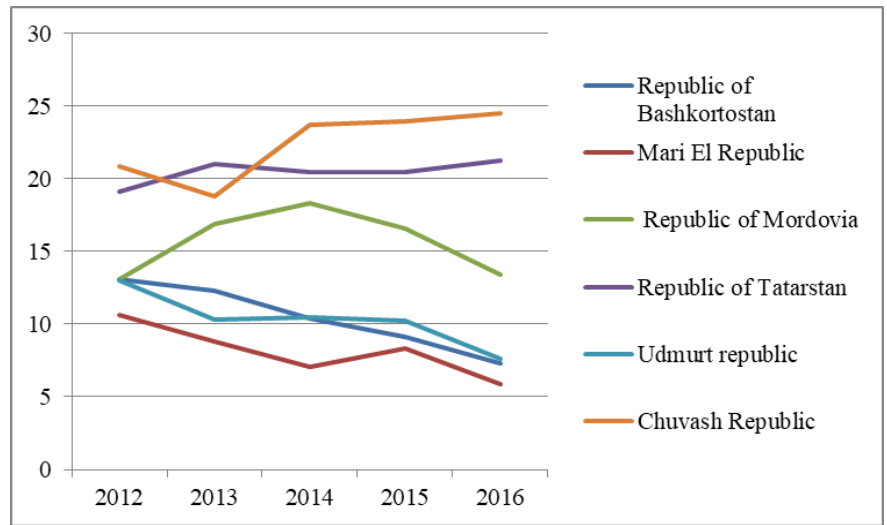

Fig. 2. Innovative activity of organizations (specific weight of organizations that carried out technological, organizational, marketing innovations in the reporting year, in the total number of organizations surveyed), in percent.

A small increase in the innovative activity of organizations also occurred in the Republic of Mordovia and amounted to $2.3 \%$. The share of organizations that implemented innovations in 2016 was $13.4 \%$.

In the Republic of Bashkortostan, in Mari El and Udmurtia, there is a decrease in the innovative activity of organizations during the period under review. The smallest share of organizations that implemented innovations in 2016 was in Mari El and amounted to $5.9 \%$.

Comparing the indicators of innovation activity of the organizations of the region, it is impossible to draw an unambiguous conclusion about the direct impact of this indicator on the volumes of output of innovative products. Chuvashia in terms of innovation activity is the first among the republics of the Volga Federal District, however, it is last but one in terms of the output of innovative products. On the other hand, in the Republic of Mari El, the lowest rates of innovative activity and output of innovation products are observed.

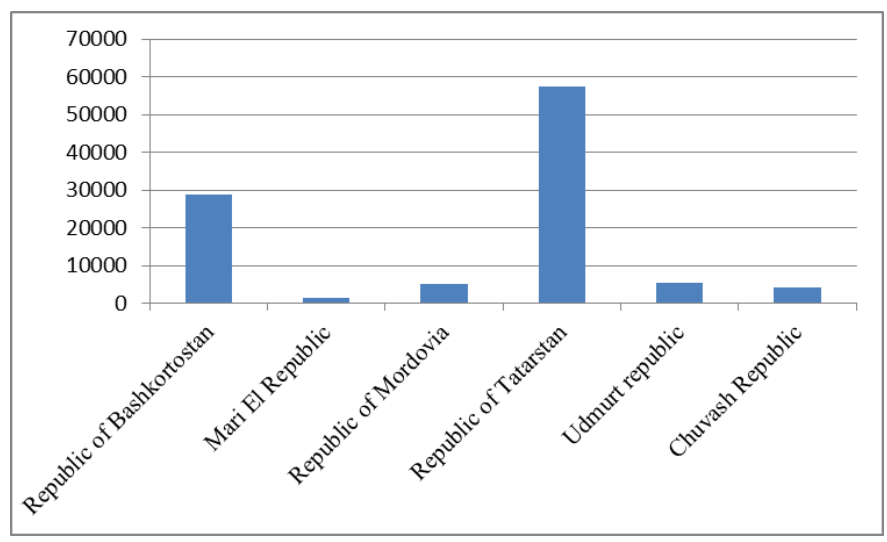

Fig. 3. Costs for technological innovation of organizations by types of innovation activities for the subjects of the Russian Federation in 2016, in million rubles.
The Republic of Tatarstan is on the first place in terms of investments in technological innovation, twice as fast as Bashkiria following it (see Fig. 3). A large share in the cost structure of the Republic of Tatarstan is occupied by research and development of new products, services and methods of their production (transfer), new production processes $(35 \%)$ and purchase of machinery and equipment (34\%).

The Republic of Bashkortostan has the following cost structure: $65 \%$ is spent on purchasing machinery and equipment, $12 \%$ - research and development of new products, services and methods of their production (transfer), new production processes, $8.5 \%$ - software acquisition, $8.5 \%$ engineering .

Bashkortostan is followed by Udmurtia, Mordovia and Chuvashia, which have approximately equal costs of technological innovation, while they are 5 times smaller than Bashkiria in terms of costs. The Republic of Mari El is the last in terms of costs for technological innovation.

Comparison of the costs of technological innovation and the volume of output of innovative products [12, 13, 14] makes it possible to identify their direct dependence. Moreover, one can see the effectiveness of investments in the Republic of Tatarstan, which is twice as fast as Bashkiria, and threefold in terms of output of innovative products.

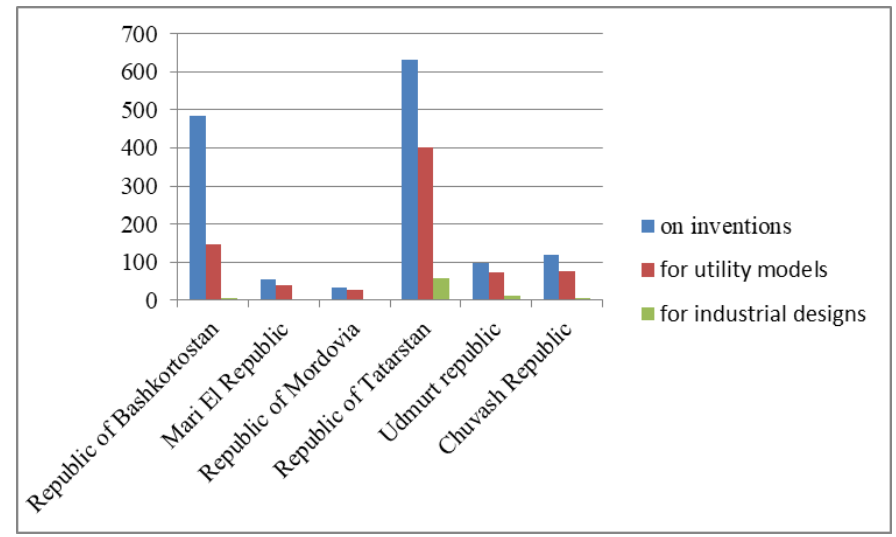

Fig. 4. Issue of titles of protection for subjects of the Russian Federation in 2016, in units

The Republic of Tatarstan is the leader in the issue of patents for inventions, utility models and industrial designs. The Republic of Bashkortostan is the second. Chuvashia and Udmurtia follow Bashkiria, having the indexes three times lower than it. The last positions are occupied by the Republic of Mari El and Mordovia. In Mordovia in 2016, only 62 patents were issued, and in Tatarstan - 1092, which can be explained by the fact that in Tatarstan the costs of research and development were 16 times higher than in Mordovia and they accordingly issued 18 times more patents in comparison with the Republic of Mordovia .

The next indicator, related to the innovative potential, is the number of personnel engaged in research and development. The Republic of Tatarstan is in the first position in this indicator, being 1.5 times ahead of following Baskiria 
(see Table 2). The Udmurt Republic goes after Bashkiria with a large margin of 4.4 times. The Republic of Mari El is the last.

TABLE II. NUMBER OF PERSONNEL ENGAGED IN RESEARCH AND DEVELOPMENT, BY SUBJECTS OF THE RUSSIAN FEDERATION, PERSONS.

\begin{tabular}{|c|c|c|c|c|c|}
\hline & 2012 & 2013 & 2014 & 2015 & 2016 \\
\hline $\begin{array}{l}\text { Republic of } \\
\text { Bashkortostan }\end{array}$ & 8166 & 8238 & 8317 & 8262 & 8008 \\
\hline Mari El Republic & 164 & 171 & 257 & 203 & 281 \\
\hline $\begin{array}{l}\text { Republic of } \\
\text { Mordovia }\end{array}$ & 902 & 946 & 885 & 990 & 927 \\
\hline $\begin{array}{l}\text { Republic of } \\
\text { Tatarstan }\end{array}$ & 13730 & 13079 & 11982 & 12708 & 12189 \\
\hline Udmurt republic & 1464 & 1636 & 1712 & 1603 & 1800 \\
\hline $\begin{array}{l}\text { Chuvash } \\
\text { Republic }\end{array}$ & 1292 & 1289 & 1326 & 1296 & 1487 \\
\hline
\end{tabular}

These indicators can be explained by the different population in the republics. For example, there is the smallest population in Mari El in comparison with the other republics, and, respectively, there is the smaller number of people engaged in scientific research. At the same time, the Republic of Bashkortostan has the greatest human potential, but is inferior to Tatarstan in terms of the number of researchers. It would be right to consider the ratio of the number of scientific workers to the total population in the republics for 2016 (see Fig. 5). This ratio is the highest in the Republic of Tatarstan, equaling to $0.3 \%$. In Bashkiria, $0.2 \%$ of the population is engaged in research and development. In Chuvashia, Udmurtia and Mordovia the ratio is about $0.1 \%$. The lowest indicator in the Republic of Mari El is $0.04 \%$.

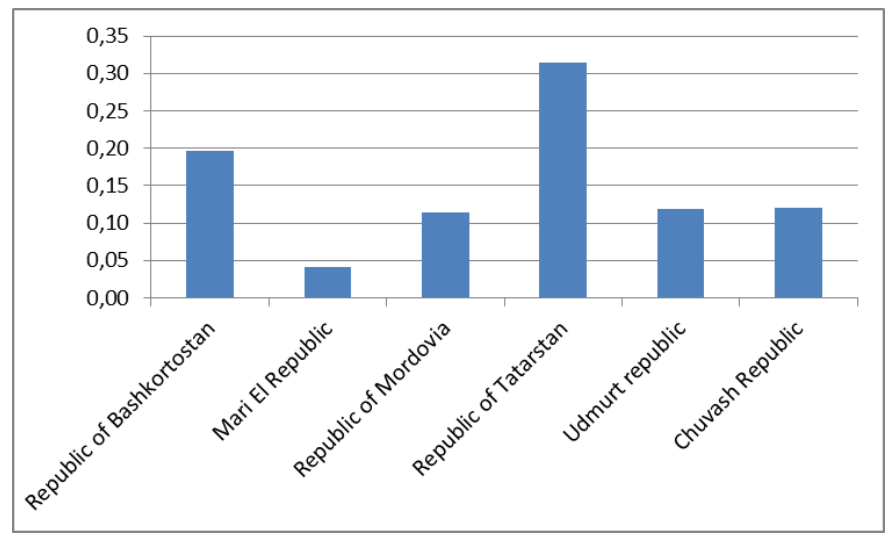

Fig. 5. Ratio of the number of personnel engaged in research and development to the total population by constituent entities of the Russian Federation for 2016, in percent.

To ensure innovative development of the region, modernization of its economy, it is necessary to create a system for training highly qualified personnel [11]. Planning the parameters of this system must take into account the requirements for the level of professional education, for the personal image of employees, which should be motivated, first of all, to be creative, initiative and persistent in the implementation of innovations. The employee should be able to effectively interact with the personnel of other professions, convince them of the need to search for weighted integrated solutions in all aspects of the urgent problems [4].

\section{RESULTS}

Obviously, the volume of innovative products of enterprises in the region is affected by many factors. On the basis of the analysis, we hypothesized that among the many factors, the share of organizations engaged in innovation activities and the number of personnel engaged in innovative development have the greatest impact.

As mentioned above, Rosstat's information on innovation activity in six regions of the Russian Federation was used as input data for five years. To test our hypothesis, we used the regression analysis method. Descriptive statistics for the variables used are presented in the table below.

\section{TABLE III. DESCRIPTIVE STATISTICS}

\begin{tabular}{|l|l|l|l|l|}
\hline & Mean & $\begin{array}{c}\text { Std. } \\
\text { Dev. }\end{array}$ & Min & Max \\
\hline $\begin{array}{l}\text { The volume of } \\
\text { innovative goods, } \\
\text { works, services, } \\
\text { million rubles. }\end{array}$ & 89799.58 & 8317 & 120003.9 & 391148.5 \\
\hline $\begin{array}{l}\text { Innovative } \\
\text { activity of } \\
\text { organizations } \\
\text { (specific weight } \\
\text { of organizations } \\
\text { that carried out } \\
\text { technological, } \\
\text { organizational, } \\
\text { marketing } \\
\text { innovations), in } \\
\text { percent }\end{array}$ & & & & \\
\hline $\begin{array}{l}\text { Number of } \\
\text { personnel } \\
\text { engaged in } \\
\text { research and } \\
\text { development, by } \\
\text { subjects of the } \\
\text { Russian }\end{array}$ & 14.57 & 5.77 & 5.9 & 24.5 \\
$\begin{array}{l}\text { Federation, } \\
\text { persons }\end{array}$ & & & & \\
\hline
\end{tabular}


THE RESULTS OF THE DEVELOPMENT OF THE REGRESSION MODEL ARE PRESENTED IN FIG. 6

\begin{tabular}{r|crc} 
Source & SS & df & MS \\
\hline $\begin{array}{r}\text { Model } \\
\text { Residual }\end{array}$ & $\begin{array}{r}3.5431 \mathrm{e}+11 \\
6.3315 \mathrm{e}+10\end{array}$ & 27 & $1.7716 \mathrm{e}+11$ \\
& $2.3450 \mathrm{e}+09$ \\
\hline Total & $4.1763 \mathrm{e}+11$ & 29 & $1.4401 \mathrm{e}+10$
\end{tabular}

$\begin{array}{rr}\text { Number of obs } & =30 \\ \text { F } 2, \quad 27) & =75.55 \\ \text { Prob }>\text { F } & =0.0000 \\ \text { R-squared } & =0.8484 \\ \text { Adj R-squared } & =0.8372 \\ \text { Root MSE } & =48425\end{array}$

\begin{tabular}{r|rrrrrr}
\hline volume_inn & Coef. & Std. Err. & \multirow{2}{*}{ t } & P $>|t|$ & [95\% Conf. Interval] \\
\hline activ & 2772.602 & 1622.771 & 1.71 & 0.099 & -557.0478 & 6102.252 \\
personnel & 22.13023 & 1.972784 & 11.22 & 0.000 & 18.08241 & 26.17805 \\
_cons & -43035.2 & 24428.81 & -1.76 & 0.089 & -93158.99 & 7088.583 \\
\hline
\end{tabular}

Fig. 6. Calculated parameters of the regression model of the dependence of the volumes of innovative products on the innovative activity of the organizations of the region and the numbe of personnel engaged in innovation activities.

As can be seen from the figure, the coefficient of determination equals 0.8484 , meaning that the model has a rather big explanatory power. However, it seems that only the number of personnel engaged in research and development is significant in explaining the volume of innovation activities without any doubt. The "activity" variable, representing the share of organisations engaged in innovation activities, has a rather high $\mathrm{p}$-value and apparently fails in explaining. This result shows us that the human capital should be considered as the most imporatant factor of the innovation activities.

\section{CONCLUSION}

Within the framework of this study, some indicators of innovation potential and their impact on the results of innovation activities were analyzed. Immediate impact on the results of innovation activities was provided by such factors as the level of costs for technological innovation and the number of personnel engaged in research and development. Moreover, the factor of effective management of investments in innovations is of great importance, which is proved by the example of the Republic of Tatarstan. There was no direct correlation between the innovative activity of the organizations of the region and the results of innovation activity, which may be due to ineffective management when introducing innovations.

To improve the results of the region's innovation activities, it is necessary to carry out work to improve human potential, which must be carried out in quantitative and qualitative directions. First, to increase the population of the region as a whole. Secondly, to cultivate your own scientific cadres or invite from outside. It is important not only to prepare our own researchers, but also to create favorable conditions for scientific work and personal life [15], so that people do not have the desire to leave their region in search of better proposals. Another direction of work is to build an effective system for managing costs for innovation $[9,10]$.

\section{References}

[1] M.F. Safargaliev, "Factors and principles of development of innovative potential of industrial enterprises", Issues of innovative economy, vol 10 , pp. 11-15, 2011, from http://www.creativeconomy.ru/articles/15484/

[2] O.G.Ivanchenko, A.Yu. Molchan, "Russia's position in the global innovation index 2016. Prospects for development in the fields of science, technology and innovation", V International scientific readings (in memory of V.F. Petrushevsky), pp. 44-50, 2016 [V International scientific readings (in memory of V.F. Petrushevsky), p. 99, 2016].

[3] Federal Service of State Statistics [Electronic resource]. Access mode: http://www.gks.ru/wps/wcm/connect/rosstat_main/rosstat/en/statistics/sc ience_and_innovations/science/\#

[4] L.L. Nadreeva, V.V. Melnichnov, M.V. Sivko, "Staffing of innovation activity", Bulletin of the Kazan State Technical University named after A.N. Tupolev, vol. 72-1, pp. 158-165, 2016.

[5] B.V. Bakeev, "Organization of a systematic approach to the analysis of innovation activity of the university", Kazan economic bulletin, vol. 4 (6), pp. 48-51, 2013.

[6] I.R. Bakeeva, B.V. Bakeev, "Trends in labor productivity in the Russian Federation and possible ways of their future correction", Economics and Entrepreneurship, vol. 11-2 (76-2), pp. 162-167, 2016.

[7] N.N. Uraev, G.F. Mingaleev, A.T. Kushimov, N.A. Kolesov, "Methodological aspects of strategic development of regional socioeconomic system (following the example of radio-electronic industry enterprises in the Republic of Tatarstan)", International Journal of Environmental and Science Education, vol. 11-12, pp. 5094-5108, 2016.

[8] R.I. Salimov, G.F. Mingaleev, "The regional policy of industrial IPM services for the development of knowledge potential in Russia", Implementing International Services: A Tailorable Method for Market Assessment, Modularization, and Process Transfer, pp. 425-435, 2012 [Implementing International Services: A Tailorable Method for Market Assessment, Modularization, and Process Transfer, pp. 449, 2012]

[9] I.R. Bakeeva, "Innovative organizational structure", Engineering Bulletin of the Don, vol. 28-1, p. 62, 2014

[10] V.M. Babushkin, N.V. Vedin, A.R. Safiullin, S.M. Valitov, "Development of scenarios and economic evaluation of implementation of the program of increase of efficiency of organization of production processes of the enterprise", Bulletin of the Kazan State Technical University named after A.N. Tupolev, vol. 71-3, pp. 98-100, 2015

[11] L.L. Nadreeva, A.G. Bashirova, "Some aspects of development of personnel development in the innovative environment", Scientific review, vol. 7-2, pp. 692-695, 2014.

[12] Yu.V. Nikolaenko, "Improvement and organization of production process of industrial enterprise on the basis of innovative methods", Bulletin of the Kazan State Technical University named after A.N Tupolev, № 2-1, pp. 199-203, 2013.

[13] A.V. Gumerov, M.K. Biktemirova, V.M. Babushkin, S.M Nuryyakhmetova, R.E. Moiseev, A.B. Nikolaeva, R.R. Kharisova, V.P. Rukomoinikova, "Quality functions modeling of industrial enterprises products", International Review of Management and Marketing, vol. 6 , issue 1, pp. 165-169, 2016.

[14] R.F. Garifullin, Yu.V. Nikolaenko, "Algorithm of technical re-training on the basis of innovation planning methods", Bulletin of Economics, Law and Sociology, vol. 2, pp. 22-27, 2012.

[15] L.L. Nadreeva, V.V. Melnichnov, V.A. Abramov, G.S. Rakhimova "Innovative complexes of Tatarstan as objects of human resources based on professionalization and polyprofessional design training of personnel”, Scientific Review, vol.16, pp. 140-149, 2016. 